\title{
NICOLAE TITULESCU: THE LINK BETWEEN THE EUROPEAN SECURITY AND THE INTERNATIONAL SECURITY. THE HERITAGE OF A POLITICAL VISION AND CONSTRUCTION.
}

\author{
Ambassador Professor Dumitru PREDA, Ph.D. ${ }^{651}$
}

\begin{abstract}
The author evokes Nicolae Titulescu' personality, thought and actions in favor of strengthening the multilateral cooperation for peace and security during the interwar period. To him - a profound democratic and visionary spirit with a solid legal, philosophical, and political background, and a considerable international experience - the long-lasting Peace means nothing if not built on the only foundation suited to support it-Security. But in his view, security has always been closely linked to the manifestation of sovereignty of independent states and national identity. In conclusion, Titulescu's political stance, his remarkable diplomatic work aiming at setting up a solid European and international security system able to deter the aggressor, bring peace and raise trust among nations, continue to be a stimulative example and an appeal still valid in its fundamental nature for the necessary and constructive steps to be taken in order to give meaning and continuity to our lives in the Third Millennium when we have to face so many crucial existential challenges.

Keywords: Nicolae Titulescu, Romania, Europe, Great Powers, Latin America, League of Nations, peace, European and International Security, alliances, The Little Entente, The Balkan Pact.
\end{abstract}

„TI-TU-LES-CU! The four syllables of his sonorous name filled up the diplomatic history after the War (the Great War) - that is what Raymond Carter, a famous journalist, wrote in L'Époque, on June 6, 1939. He added: "He was also one of Romania's greatest men, one of the Little Entente's greatest men, one of Geneva's greatest men [the League of Nations] and, to sum it up, one of Europe's greatest men. Ten times minster, eight of them as minister of Foreign Affairs. He had a tenure of ten years of ambassadorship [Plenipotentiary Ministry] in London but continued to be the inspiration, the engine of the Romanian diplomacy. He was the most brilliant and dynamic one of all who wanted to build a new Europe,

\footnotetext{
${ }^{651}$ Professor Dumitru Preda Ph.D. is historian and career diplomat. Currently, Professor Preda is Scientific Director of the "Titulescu" European Foundation. Professor Preda previously served as Ambassador Extraordinary and Plenipontentiaryof the Republic of Romania to the Republic of Cuba (2011-2016), Director of the Diplomatic Archives Directorate (1997-2002) and Permanent Delegate of Romania and Chargée d'Affaires A.I. to UNESCO (2002-2007).
} 
based on the equity of powers and the respect of treaties [...] Openly admired and overly criticized, he was in the eye of the hurricane, of the battle..."

There is no doubt that the prominent personality of this Statesmen and Politician - who passed away 80 years ago - his vast political al diplomatic work caught the interest of his contemporaries and continues to be a model and an inspiration for the current and future generations ${ }^{653}$. That is why, despite the passage of time, more and more studies, books, or collections of documents pertaining to his work are still being published. They highlight the facts and the features of a prodigious activity, his personal and impressive style always put in the service of his Country and his people's needs.

His admirable and consistent views on peace and security policy in Europe and in the world, on the necessity of economic and intellectual cooperation in favor of the progress of humanity, but mostly his noble example of work and action for the defense of the independence and integrity of the Romanian unitary state (to whose consolidation he had contributed during the First World War and at the Paris Peace Conference in 1919-1920), his intuitive vision regarding Romania's integration in the European architecture but, at the same time, maintaining its distinct role and specific national identity, all these are authentic arguments that make the meaning of his complex work extremely actual ${ }^{654}$.

"I am Romanian, born of Romanian parents, raised in the spirit of the principles of Take Ionescu and Vintilă Brătianu - wrote Titulescu in 1936, in a letter addressed, in his capacity of Minister of Foreign Affairs, to the President of

\footnotetext{
${ }^{652}$ Cf. Pro şi Contra Titulescu, ed. George G. Potra, Editura Enciplopedică, București, 2002, p. 87.

${ }^{653}$ Ion M. Oprea, Nicolae Titulescu, Editura Ştiinţifică, Bucharest, 1966; Nicolae Titulescu. Discursuri, ed. Robert Deutsch, Editura Ştiinţifică, Bucharest, 1967; Nicolae Titulescu, Documente diplomatice, ed. George Macovescu, Dinu C. Giurescu, Gheorghe Ploeşteanu, George G. Potra, Constantin I. Turcu, Editura Politică, Bucharest, 1967 (Second edition, coord. Dumitru Preda, Editura Fundaţiei Europene Titulescu, Bucharest, 2021); Ion Grecescu, Nicolae Titulescu, Editura Politică, Bucharest, 1980; Idem, Nicolae Titulescu. Concepție juridică şi diplomatică, Editura Scrisul Românesc, Craiova, 1982; Titulescu și strategia păcii, coord. Gheorghe Buzatu, Editura Junimea, Iași, 1982; Constantin I. Turcu, Ion Voicu, Nicolae Titulescu în universul diplomaţiei păcii, Editura Politică, Bucharest, 1984; Milan Vanku, Nicolae Titulescu, promotor al politicii de pace şi colaborare în Balcani 19201936, Editura Politică, Bucharest, 1986; Ion Grecescu, Nicolae Titulescu. Documente confidențiale, Editura Academiei Române, Bucharest, 1992; Adrian Năstase, Nicolae Titulescu, contemporanul nostru/Notre contemporain, Editura Metropol, Bucharest, 1995 (Second edition reviewed, RA Monitorul Oficial, Bucharest, 2002; Ion Grecescu, Vasile Popa, Gândirea juridico-diplomatică a lui Nicolae Titulescu, Chişinău, 1997; George G. Potra, Titulescu. Spre Ţara Drepților, Slatina, 2001; Titulescu, Un mare Român, un mare European, un mare Contemporan, O restituire foto-documentară by George G. Potra, Cristina Păiuşan, Dumitru Preda; Foreword by Adrian Năstase, Fundaţia Europeană Titulescu, Bucharest, 2002; Nicolae Titulescu, Opera politico-diplomatică (iulie 1927-iulie 1928), vol. I-II, ed. George G. Potra, Costică Prodan, Foreword by Adrian Năstase, Fundaţia Europeană Titulescu, Bucharest, 2003; Nicolae Titulescu, Opera politico-diplomaticăa. Corespondenţă, vol. I (1921-1931), ed. George G. Potra, Foreword by Adrian Năstase, Fundaţia Europeană Titulescu, Bucharest, 2004; Nicolae Titulescu, Opera politico-diplomatică (1 ianuarie 1937-31 decembrie 1937), I-III, ed. George G. Potra; Foreword by Adrian Năstase, Fundaţia Europeană Titulescu, Bucharest, 2007 Adrian Năstase, George G. Potra, Titulescu - Ziditor de mari idealuri, Fundaţia Europeană Titulescu, Bucharest, 2007; Pro şi Contra Titulescu, Second edition reviewed, ed. George G. Potra, vol. I-III, Fundaţia Europeană Titulescu, Bucharest, 2012; Nicolae Titulescu, Opera politico-diplomatică. Corespondenţă (1920-1939), ed. George G. Potra, vol. II, Fundaţia Europeană Titulescu, Bucharest, 2013.

${ }^{654}$ See also the review "Perspective" (Titulescu European Foundation), $n^{\circ} 1$ (3)/2021, coord. Dumitru Preda, number dedicated to Nicolae Titulescu.
} 
the Council of Ministers, Gheorghe Tătărescu - and therefore, to me, the Romanian nationalism is a creed I exercised abroad and inside my country. For this reason, I demand that no foreigner interfere in our domestic issues and the guiding lines of our national policy remain purely Romanian " 655 . These were the key coordinates of his foreign policy.

His talent, his skills and his legal, political, and financial knowledge founded on a remarkable erudition and a practical experience he had acquired in extremely tensed international circumstances, his unmistakable eloquence, and his ability to manage different issues, his intelligence, his flexibility, and his courage based on a thorough groundwork and balanced decision making, Nicolae Titulescu knew how to use them all to defend the key interests of the Romanian State.

As a fine observer of the political, economic, social, and cultural evolutions of his time that he would pass through the filter of his insightful spirit and confident judgment so much acknowledged and appreciated by his contemporaries, his collaborators, or his opponents, Titulescu closely followed, between 1918-1920, the international developments, the stances and the reactions of the Great Powers after the Great War - either victorious or defeated - within the context of the changes that occurred in the new geopolitical European architecture and the world's balance of forces. This was a dynamic process generated by conflicting interests and obvious contradictions in the fight for resources and domination of large areas outside Europe, both being amplified as historical analysis revealed later on - by a staggering narrow-mindedness of the Western governments in the face of the right-wing, fascist currents and revisionist actions, mostly in the 1930's. Preserving and consolidating balance (the statu-quo after 1920) and peace would become the central axis of Titulescu's political thought and assiduous political action. It was, in his view, the only way to preserve the unity of the national State that had been earned with the sacrifice of over a million Romanians, as the sole guarantee of the democratic development of the Romanian society.

Nicolae Titulescu proved, in accordance with this vision and without ignoring the lessons of history that had been so painful to Romanians or other small and medium size Powers, a realistic and pragmatic view ${ }^{656}$. By identifying

\footnotetext{
655 Nicolae Titulescu, Politica externă a României/Romania's Foreign Policy/ (1937), ed. George G. Potra, Constantin I. Turcu, Ion M. Oprea, Editura Enciplopedică, Bucharest, 1994, p. 38. Cf. Idem, La politique extérieure de la Roumanie (1937), II édition, Foreword by Adrian Năstase, Editura Muzeul Literaturii Române, Bucharest, 2018, p. 36.

${ }^{656}$ Constantin Hlihor, Nicolae Titulescu şi arhitectura de securitate a Europei. Între idealism wilsonian şi realism politic [Nicolae Titulescu and the security architecture of Europe. Between Wilsonian idealism and political realism], in "Perspective", n 1 (3)/2021, p. 73-98. In a conference held in the German Reichstag, on May 6, 1929 (Die Dynamik des Friedens), Titulescu stated that people are not only divided between realists and idealists, and that there is a third category, namely that of "idealistic producers, or more precisely, of the idealists who want, who try to achieve (doers)". (Full text in Nicolae Titulescu, Discursuri [Speeches], Editura Ştiinţifică, Bucharest, 1967, pp. 317-335; see also Nicolae Titulescu. Pledoarii pentru pace [Plea for peace], ed. George G. Potra, Constantin I. Turcu, Editura Enciplopedică, Bucharest, 1996, pp. 149-172; 174-200, in German).
} 
the threats to his country, he undertook progressive actions to create a defensive system of alliances based on the international legal instruments of the Statute of the League of Nations from 1919: the Little Entente - the first regional organization created in 1920-1921 and reformed in 1933 $3^{657}$, the Balkan Pact from 1934, the Non-Aggression Pact from 1933 signed with the USSR etc. The same Titulescu would state: "I never grounded Romania's security exclusively on the Pact of the League of Nations" "658.

At the same time, by promoting and signing essential diplomatic documents which would strengthen Romania's status and relations with countries from other continents, he acted in favor of an active multilateral cooperation that would build trust and give hope to peace, security, and stability of international relations.

As the researchers of Nicolae Titulescu's political and diplomatic work emphasized, the Romanian Statesman and Diplomat always envisioned the situation and the destiny of his country as part of Europe, but he never made the distinction between Eastern and Western Europe, considering the Old Continent as a unitary space where Romanians and Romania must have a well-defined and respected place. When he understood the frailty of the peace treaties and the conflicting situations that occurred once they had been concluded, Titulescu broadened his action in favor of security and disarmament as pillars of peace beyond Europe, thereby establishing a direct link between Europe's and world's security.

He permanently aimed, from the rostrum of the League of Nations as Minister of Foreign Affairs, at implementing this vision by supporting regional initiatives not only in Europe, but on other continents as well ${ }^{659}$. Collective security meant, in his view, removing the force and the threat of recourse to force as "legal instrument" for the resolution of conflicts between states, as well as setting up those international legal instruments ensuring the respect of norms and principles of the international law among world's nations, regardless of their size or economic and military capabilities.

As he constantly used to stress out, the foreign policy he promoted was founded on collective security and undivided peace and aimed at "creating a united front of potential victims of an aggression against the united front of potential aggressors". It was an innovative and constructive approach in an unsettled world dominated by numerous contradictions and violent manifestations of militarism and fascism against the background of the world economic crisis (1929-1933). Besides his appeal in favor of a new model of security, he also drew the attention on the unequivocal responsibility of the Great Powers to identify ways and carry out concrete actions in favor of peace.

\footnotetext{
${ }^{657}$ Nicolae Titulescu, Documente diplomatice [Diplomatic Documents], doc. 274 (pp. 474-483).

${ }^{658}$ Idem, Discursuri [Speeches], p. 537.

${ }^{659}$ George G. Potra, Studiu introductiv [Introductory study], in Nicolae Titulescu. Pledoarii pentru pace [Plea for peace], pp. 60-61.
} 
"Peace is an absolute necessity for the whole Europe" - said the Romanian Minister of Foreign Affairs in an interview given to the press in Belgrade, after the Little Entente's reunion, in June 1928. "This necessity is perfectly understood by all nations that are aware of the transformations caused by the war and its consequences; our imperative need is to always be prepared to resist a damaging situation to all of us, through a permanent work of reconstruction [...] There cannot be a real peace - he added - without a complete trust, shared by everyone, in the stability of the existing agreements "660.

"The treaties in force - Titulescu also stated - may seem imperfect to many. But even so, there should be no surprise because treaties are made by us, humans". Stating that "to us, the intangibility of borders is not a doctrine born out of national selfishness, unawareness or narrow-mindedness", he clearly pointed out: "The intangibility of treaties is in the best interest of all, not in the specific interest of some, it is the sine qua non condition for peace safeguarding" $" 661$.

We would also like to note his metaphorical view pertaining to the aim of the Romanian-Yugoslav-Czechoslovakian alliance in international affairs and the strengthening of European security: "I see The Little Entente as an embankment of a huge harbor [...] The protected harbor is Europe and the sea whose stillness it is trying to maintain is Europe's peace" ${ }^{" 662}$.

Given the shifting ratio of the Peace-War equation, under the influence of the heterogenous social and political factors (such as the rise of Bolshevik and anarchic movements against the above-mentioned world economic crisis) and the more and more enhanced revisionist states' reactions after 1930, Nicolae Titulescu would demonstrate once again his geopolitical realism by initiating and subsequently signing the Balkan Pact (by Turkey, Yugoslavia, Greece and Romania) aiming at enhancing collective security and deterring threats in SouthEastern and Central Europe and in Eastern Mediterranean ${ }^{663}$.

"The idea that guide us, the creators of the Balkan Pact, is simple - stated the Romanian Minister in his speech at the official dinner hosted by the Greek Government. We are eager for peace. But I know that the real peace is based on trust and trust is based on stability. The first solid pillar a State is seeking out for, not out of selfishness but in the best interest of all, is the stability of its borders. [...] The Athens Treaty is, above all, an action required by the survival instinct

\footnotetext{
${ }^{660}$ „Dimineața” [The Morning, Bucharest], June 17, 1928, in Nicolae Titulescu. Opera politico-diplomatică, iulie 1927-iulie 1928 [Political and Diplomatic Work, July 1927-July 1928], Part II, doc. 350 (p. 890).

661 Ibidem.

${ }^{662}$ Ibidem (p. 891). About alliance concerned, see the classic work of Eliza Campus, Mica Înţelegere [The Little Entente], Editura Ştiinţifică şi Enciplopedică, Bucharest, 1968; Second edition, Editura Academiei Române, Bucharest, 1997.

${ }^{663}$ Cristian Popişteanu, România şi Antanta Balcanică [Romania and the Balkan Entente], Editura Politică, Bucharest, 1968 (Second edition, 1971). Cf. Eliza Campus, Inţelegerea Balcanică [The Balkan Entente], Editura Academiei, Bucharest, 1972; see also Alexandru Oşca, Managementul crizelor regionale. Modelul balcanic interbelic [Regional Crisis Management. The interwar Balkan model], Editura AISM, Bucharest, 2003.
} 
[...], a work of political realism in the service of peace [...], a work of justice respecting the rights of the others and inviting all interested parties in joining the legal framework designed by the signatory states [...]. That is why we are ready to carry out, together with all those who will definitively and loyally acknowledge our borders, an extensive work of economic and political cooperation [...] Security, good understanding, association, and integration, these are the four pillars of the temple we have built to peace today..." "664.

Romania and Yugoslavia having joined the Little Entente, the collective security system consequently became considerably consolidated and extended which would cause annoyance to the group of the revisionist states (Germany, Italy, Hungary, and Bulgaria). Those would soon act to undermine the system ${ }^{665}$.

Nicolae Titulescu had paid a special attention to the political developments in South and Central America and, both in Geneva at the League of Nations and as Minister of Foreign Affairs, he had showed a clear readiness to build relationships with the respective countries. He had a good communication and personal connections with important Latin American diplomats and jurists. He also inaugurated the first diplomatic missions in Brazil (1927), Argentina (1928), Mexico, Chile, and Uruguay (1935) and Venezuela (1936) ${ }^{666}$. In 1934, Nicolae Titulescu would initiate the process of accession of the Little Entente's member states to The Anti-war Treaty of Non-aggression and Conciliation (also known as Saavedra Lamas Treaty) signed in Rio de Janeiro a year before, on October 10, $1933^{667}$. In this respect, on December 12, 1934, he addressed a note to the Argentinian ambassador in Rome, José María Cantilo, in which "he conditioned - as revealed by the cable sent to Bucharest two days later - the accession [...] by the remaining in force, without any change, of the previous commitments, such as the Pact of the League of Nations, the alliance treaties ... [...]. The Balkan Pact - he concluded - will send an identical note "668 (author's highlight).

\footnotetext{
${ }^{664}$ Nicolae Titulescu, Documente diplomatice [Diplomatic Documents], doc. 307 (pp. 546-547).

${ }^{665}$ On the geo-political developments of these years, see at Eliza Campus, Din politica externă a României [From Romania's Foreign Policy] 1913-1947, Editura Politică, Bucharest, 1980; Mihai Retegan, In balanţa forţelor: alianţa militare româneşti interbelice [In the balance of forces: interwar Romanian military alliances], Editura Semne, Bucharest, 1997, passim; Em. Bold, I. Ciupercă, Europa în derivă [Europe drifting] (1918-1940). Din istoria relaţiilor internaţionale [From the history of international relations], Casa Editorială Demiurg, Iaşi, 2001 (Second edition, 2010).

${ }^{66}$ Dr. Juan Mariátegui, Ministrul de Externe român Nicolae Titulescu şi America Latină [Romanian Foreign Minister Nicolae Titulescu and Latin America], in „Revista de ştiinţe juridice” [Journal of Legal Sciences], Craiova, $\mathrm{n}^{\text {os }}$ 1-2/2005, pp. 156-161; Doru Bratu, Istoria relaţiilor României cu ţările Americii Latine [History of Romania's relations with Latin American countries] (1866-2000), Editura Fundaţiei România de Mâine, Bucharest, 2004, passim. Cf. Constantin Buşe, Intre Panama şi San Francisco. America Latină în lume [Between Panama and San Francisco. Latin America in the world], Editura Ştiinţifică, Bucharest, 1991, pp. 334-335.

${ }^{667}$ The treaty, which supplemented the provisions of the Briand-Kellogg Pact of 1928, had been proposed by Carlos Saavedra Lamas, the Argentine Minister of Foreign Affairs (1932-1938), and was signed by the governments of Argentina, Brazil, the United States, Mexico, and Paraguay. Uruguay and Chile. The pact called for the organization of a permanent system of conciliation on the issue of international conflicts, leading to the prevention of war, and the aim was to broaden the foundations of cooperation in the peacekeeping effort between Latin American, European and American states.

${ }^{668}$ Nicolae Titulescu, Documente diplomatice [Diplomatic Documents], doc. 339 (pp. 589-590).
} 
"The delegates from South America - would write down Titulescu in his book Romania's Foreign Policy - come to Geneva with an ideal, the collective security. Where the debates and the resolutions adopted in Geneva stop advancing, the South American countries fulfill the work of organizing the peace by concluding treaties tailored to suit their needs, such as The Saavedra Lamas Treaty and the Pan-American Pacts ${ }^{669}$. The presence of Latin-Americans to the League of Nations makes the organization universal"670.

Evoking the personality and actions of Nicolae Titulescu in favor of strengthening the multilateral cooperation with the Latin-American states, Adrian Năstase, the young Romanian Minister of Foreign Affairs at that time stated, in a speech delivered on July 10, 1991, at the National Academy of Venezuela: "The accession of our country, along with 32 other states, to The Anti-war Treaty of Non-aggression and Conciliation Saavedra Lamas would have allowed - had the other America, from the North, joined it - a more courageous reaction from the Western democracies in the face of the aggressive forces, would have prevented the Second World War and imposed the core principles of Titulescu's political model: a complete establishment of the democratic rule of law at the national level and a full compliance with the international legal instruments" ${ }^{\prime 671}$.

Nicolae Titulescu constantly condemned, along with his Latin-American colleagues, the aggressive actions from 1935 against the independence and the sovereignty of Abyssinia (Ethiopia), the occupation of the demilitarized zone of Rhineland in 1936, and later on, in 1937, Japan's aggression in China.

To him - a profound democratic and visionary spirit with a solid legal, philosophical, and political background, and a considerable international experience - the long-lasting Peace means nothing if not built on the only foundation suited to support it - Security. But in his view, security has always been closely linked to the manifestation of sovereignty of independent states and national identity: "To envisage the abolition of sovereignty as a solution for longlasting peace - he noted in the well-known Dictionnaire diplomatique published by A.F. Frangulis - means not only to envisage an impossible solution but alsoif going down this road - to throw the world into chaos and anarchy [...] To envisage the abolition of the national identity as a solution for long-lasting peace is not only impossible, but it would deprive the human being of the very essence of its current individuality" ${ }^{\prime \prime 72}$.

Titulescu's political stance, his remarkable diplomatic work aiming at setting up a solid European and international security system able to deter the

\footnotetext{
${ }^{669}$ Reference to the Treaty for the Elimination or Prevention of Conflicts between American States (Gondra Treaty), signed at Santiago de Chile (May 3, 1923); The General Inter-American Arbitration Treaty, signed in Washington (January 5, 1929), as well as The General Convention on Inter-American Conciliation (Washington, January 5, 1929).

${ }^{670}$ Nicolae Titulescu, Politica externă a României/Romania's Foreign Policy, p. 204.

${ }^{671}$ Adrian Năstase, Nicolae Titulescu. Contemporanul nostru [Nicolae Titulescu. Our Contemporary], pp. 71-72.

${ }^{672}$ Nicolae Titulescu, Documente diplomatice [Diplomatic Documents], doc. 491 (p. 845).
} 
aggressor, bring peace and raise trust among nations, continue to be a stimulative example and an appeal still valid in its fundamental nature for the necessary and constructive steps to be taken in order to give meaning and continuity to our lives in the Third Millennium when we have to face so many crucial existential challenges.

We need Titulescu, his bright philosophy, his intuitive authority, and the determination he proved while fighting for the greater and lasting interests of his Country. Therefore, we repeat what Professor Nicolae Basilescu, the Dean of the Faculty of Law of Bucharest, said almost 90 years ago: Nicolae Titulescu is a national treasure[...] Nolli eum tangere! $!^{673}$

\section{BIBLIOGRAPHY}

- Bold E., Ciupercă I., Europa în derivă [Europe drifting] (1918-1940). Din istoria relaţiilor internaţionale [From the history of international relations], Casa Editorială Demiurg, Iaşi, 2001 (Second edition, 2010);

- Bratu D., Istoria relaţiilor României cu ţările Americii Latine [History of Romania's relations with Latin American countries] (1866-2000), Editura Fundaţiei România de Mâine, Bucharest, 2004, passim;

- Buşe C., Intre Panama şi San Francisco. America Latină în lume [Between Panama and San Francisco. Latin America in the world], Editura Ştiinţifică, Bucharest, 1991;

- Buzatu G. (coord), Titulescu și strategia păcii, Editura Junimea, Iași, 1982;

- Campus E., Din politica externă a României [From Romania's Foreign Policy] 1913-1947, Editura Politică, Bucharest, 1980;

- Campus E., Inţelegerea Balcanică [The Balkan Entente], Editura Academiei, Bucharest, 1972;

- Campus E., Mica Înţelegere [The Little Entente], Editura Ştiinţifică şi Enciplopedică, Bucharest, 1968; Second edition, Editura Academiei Române, Bucharest, 1997;

- Deutsch R. (ed.), Nicolae Titulescu. Discursuri, Editura Ştiinţifică, Bucharest, 1967;

- Grecescu I., Nicolae Titulescu, Editura Politică, Bucharest, 1980;

- Grecescu I., Nicolae Titulescu. Concepție juridică şi diplomatică, Editura Scrisul Românesc, Craiova, 1982;

- Grecescu I., Nicolae Titulescu. Documente confidențiale, Editura Academiei Române, Bucharest, 1992;

\footnotetext{
${ }^{673}$ Pro şi Contra Titulescu [Pro and Against Titulescu], pp. 42-43. „, Don't touch Me! (John, 20, 17). Words that Jesus Christ would have addressed to Mary Magdalene on the morning of the Resurrection. Their meaning is: Do not touch this man or thing.
} 
- Grecescu I., Popa V., Gândirea juridico-diplomatică a lui Nicolae Titulescu, Chişinău, 1997;

- Hlihor C., Nicolae Titulescu şi arhitectura de securitate a Europei. Intre idealism wilsonian şi realism politic [Nicolae Titulescu and the security architecture of Europe. Between Wilsonian idealism and political realism], in "Perspective", no 1 (3)/2021;

- La politique extérieure de la Roumanie (1937), IIe édition, Foreword by Adrian Năstase, Editura Muzeul Literaturii Române, Bucharest, 2018;

- Macovescu G., Giurescu D.C., Ploeşteanu G., Potra G.G., Turcu C.I. (ed.), Nicolae Titulescu, Documente diplomatice, Editura Politică, Bucharest, 1967 (Second edition, coord. Dumitru Preda, Editura Fundaţiei Europene Titulescu, Bucharest, 2021);

- Mariátegui J. (Dr.), Ministrul de Externe român Nicolae Titulescu şi America Latină [Romanian Foreign Minister Nicolae Titulescu and Latin America], in „Revista de ştiinţe juridice” [Journal of Legal Sciences], Craiova, nos 12/2005;

- Năstase A., Nicolae Titulescu, contemporanul nostru / Notre contemporain, Editura Metropol, Bucharest, 1995 (Second edition reviewed, RA Monitorul Oficial, Bucharest, 2002);

- Năstase A., Potra G.G., Titulescu - Ziditor de mari idealuri, Fundaţia Europeană Titulescu, Bucharest, 2007;

- Nicolae Titulescu, Discursuri [Speeches], Editura Ştiinţifică, Bucharest, 1967;

- Oprea I.M., Nicolae Titulescu, Editura Ştiinţifică, Bucharest, 1966;

- Oşca A., Managementul crizelor regionale. Modelul balcanic interbelic [Regional Crisis Management. The interwar Balkan model], Editura AISM, Bucharest, 2003;

- Popişteanu C., România şi Antanta Balcanică [Romania and the Balkan Entente], Editura Politică, Bucharest, 1968 (Second edition, 1971);

- Potra G.G., Pro şi Contra Titulescu, Editura Enciplopedică, Bucureşti, 2002;

- Potra G.G., Titulescu. Spre Ţara Drepților, Slatina, 2001;

- Potra G.G. (ed.), Nicolae Titulescu, Opera politico-diplomatică. Corespondenţă, vol. I (1921-1931), Foreword by Adrian Năstase, Fundaţia Europeană Titulescu, Bucharest, 2004;

- Potra G.G. (ed.), Nicolae Titulescu, Opera politico-diplomatică. Corespondenţă (1920-1939), vol. II, Fundaţia Europeană Titulescu, Bucharest, 2013;

- Potra G.G. (ed.), Nicolae Titulescu, Opera politico-diplomatică (1 ianuarie 1937-31 decembrie 1937), I-III, Foreword by Adrian Năstase, Fundaţia Europeană Titulescu, Bucharest, 2007;

- Potra G.G., Nicolae Titulescu. Pledoarii pentru pace [Plea for peace], Constantin I. Turcu, Editura Enciplopedică, Bucharest, 1996, (in German); 
- Potra G.G., Păiuşan C., Preda D., Titulescu. Un mare Român, un mare European, un mare Contemporan. O restituire foto-documentară. Foreword by Adrian Năstase, Fundaţia Europeană Titulescu, Bucharest, 2002;

- Potra G.G., Prodan C., Nicolae Titulescu, Opera politico-diplomatică (iulie 1927-iulie 1928), vol. I-II, Foreword by Adrian Năstase, Fundaţia Europeană Titulescu, Bucharest, 2003;

- Potra G.G., Turcu C.I., Oprea I.M. (ed.), Nicolae Titulescu, Politica externă a României / Romania's Foreign Policy / (1937), Editura Enciplopedică, Bucharest, 1994;

- Preda D. (coord.), Review "Perspective" (Titulescu European Foundation), no 1 (3)/2021, number dedicated to Nicolae Titulescu;

- Retegan M., In balanţa forţelor: alianţa militare româneşti interbelice [In the balance of forces: interwar Romanian military alliances], Editura Semne, Bucharest, 1997, passim;

- Turcu C.I., Voicu I., Nicolae Titulescu în universul diplomaţiei păcii, Editura Politică, Bucharest, 1984;

- Vanku M., Nicolae Titulescu, promotor al politicii de pace şi colaborare in Balcani 1920-1936, Editura Politică, Bucharest, 1986. 